\title{
Growth inhibition and apoptotic effects of total flavonoids from Trollius chinensis on human breast cancer MCF-7 cells
}

\author{
SHUHUA WANG $^{1}$, QINGQING TIAN ${ }^{1}$ and FANG AN ${ }^{2}$ \\ ${ }^{1}$ Department of Pharmacy; ${ }^{2}$ Graduate Faculty, Hebei North University, Zhangjiakou, Hebei 075000, P.R. China
}

Received March 19, 2015; Accepted June 2, 2016

DOI: $10.3892 / 01.2016 .4898$

\begin{abstract}
Dried flowers of Trollius chinensis have long been used as an important traditional Chinese medicine. Previous studies have demonstrated the ability of T.chinensis flavonoids to reduce the proliferation of human breast cancer MCF-7 cells. The present study further investigated the influence of $T$. chinensis flavonoids on the growth and proliferation of MCF-7 cells and observed clear inhibitory effects within the concentration range of 0.0991-1.5856 mg/ml. Apoptosis was triggered by $T$. chinensis flavonoids treatment that was evaluated by differential interference contrast software, the Hoechst 33258 method, scanning electron microscopy, hematoxylin/eosin staining and laser confocal light microscopy. Cells treated with $T$. chinensis flavonoids selectively reduced bcl-2 and $\mathrm{NF}-\kappa \mathrm{B}$ expression and increased the expression of caspase- 9 and caspase- 3 indicating that the inhibition of cellular proliferation occurred through activation of a mitochondrial pathway. Taken together, the results confirmed the ability of $T$. chinensis flavonoids to inhibit cell proliferation.
\end{abstract}

\section{Introduction}

Breast cancer is the most common type of cancer in women. Over the past 30 years, the morbidity of breast cancer has increased at a rate of $3 \%$ each year in china (1). Surgery combined with chemotherapy and radiotherapy is the main therapeutic approach for this disease, but severe side effects occur in the course of these treatments. Therefore, effective antitumor therapeutic drugs with few side effects need to be developed.

The dried flowers of Trollius chinensis is used as a common traditional Chinese medicine. Modern pharmacological studies have shown that it possesses antimicrobial, antiviral (2),

Correspondence to: Mr. Fang An, Graduate Faculty, Hebei North University, 11 South Diamond Road, Zhangjiakou, Hebei 075000, P.R. China

E-mail: wangshyh@126.com

Key words: apoptosis, breast cancer, caspase, MCF-7, Trollius flavonoids anti-oxidative and anti-tumor activities and has been used widely to treat chronic tonsillitis and upper respiratory infections in clinical therapy (3).

Flavonoids as the major constituents of T. chinensis (4) possess antimicrobial, anti-inflammatory, hypotensive, antiviral, spasmolysis and antioxidant effects (in vitro and in vivo) (5-9). Currently, T. chinensis flavonoids are used for their antibacterial and antioxidant properties $(10,11)$. A preliminary study demonstrated the strong inhibitory effects of T. chinensis flavonoids in K562, HeLa, EC-109 and NCI-H446 cells (12). T. chinensis flavonoids were also demonstrated to inhibit the proliferation of A549 cells in a dose-dependent manner, and the effect was associated with the expression of apoptosis-related genes (13). Another previous study showed the ability of $T$. chinensis flavonoids to dose-dependently inhibit the proliferation of MCF-7 cells, and telomerase activity decreased progressively with increasing drug concentrations (14); however, cellular apoptosis has not been verified from a morphological perspective, and the mechanism of action has not been clarified. Therefore, the current study was conducted to examine apoptosis induced by T. chinensis flavonoids in MCF-7 cells by different methods, including MTT assay, differential interference contrast (DIC), Hoechst staining, scanning electron microscopy, hematoxylin and eosin (HE) staining, Annexin-V/propidium iodide (PI) double-labeling and western blot analysis, in order to clarify the underlying biochemical mechanisms and facilitate clinical anti-tumor drug development.

\section{Materials and methods}

Drugs andreagents. 3-(4,5)-dimethlythiahiazo-z-y10-3,5-diphenytetrazoliumromide (MTT) was purchased from Sigma-Aldrich (St. Louis, MO, USA). Annexin V-FITC/PI was manufactured by Beijing Zhaungmeng Science and Technology Limited Company (Beijing, China). Hoechst 33258 dye was obtained from Sigma-Aldrich. Total flavonoids were dissolved in DMSO and diluted with culture media immediately prior to use. Primary and secondary antibodies were manufactured by Beijing Boaosen Biotechnology Limited Company (Beijing, China). The T. chinensis flavonoids were prepared as previously described (15) with a purity of $\sim 68 \%$.

Cell culture and experimental groups. MCF-7 breast cancer cells maintained at the Medical Genetics Department of 
Beijing Cancer Institute were cultured in RPMI-1640 (Gibco, ThermoFisher Scientifc, Inc., Waltham, MA, USA) medium supplemented with $10 \%$ fetal bovine serum (FBS), $100 \mu \mathrm{M} / \mathrm{ml}$ gentamicin at $37^{\circ} \mathrm{C}$ in an atmosphere with $5 \% \mathrm{CO}_{2}$. Cells were subcultured and passaged at $\sim 70-80 \%$ confluency. Cells in the logarithmic phase were used in all experiments. Total flavonoids were extracted from $T$. chinensis. Stock solutions, kept at $-20^{\circ} \mathrm{C}$, were diluted to the final concentrations with culture medium prior to use. The final DMSO concentration was below $0.2 \%$ in all experiments.

Growth inhibition assay. The effect of total flavonoids on cell growth was evaluated by using an MTT assay. Briefly, cells were seeded at $10^{5}$ cells $/ \mathrm{ml}$ in 96 -well plates for the assay. After culturing with flavonoids at different concentrations $(0,0.0991,0.1982,0.3964,0.7928$ or $1.5856 \mathrm{mg} / \mathrm{ml})$ for various times (24, 48 or $72 \mathrm{~h}), 20 \mu \mathrm{l}$ of MTT was added to each well. Plates were incubated for another $4 \mathrm{~h}$ at $37^{\circ} \mathrm{C}$, and then the medium was aspirated by pipetting and replaced with $100 \mu 1 /$ well DMSO in order to dissolve the formazan produced by viable cells exposed to MTT. The absorbance reflecting the cell growth was measured at $490 \mathrm{~nm}$ with a microplate reader. All data were obtained from 4 independent experiments and expressed as the mean \pm standard deviation.

DIC microscopy and Hoechst33258 staining. Morphological changes were detected with Hoechst dye staining. Cells were seeded $\left(10^{5} \mathrm{cells} / \mathrm{ml}\right)$ on coverslips overnight and then treated with flavonoids at different concentrations $(0,0.0991,0.1982$, $0.3964,0.7928$ or $1.5856 \mathrm{mg} / \mathrm{ml}$ ) for $24 \mathrm{~h}$. Thereafter, the coverslips were washed with PBS and fixed with $4 \%$ paraformaldehyde for $1 \mathrm{~h}$. After washing the cells with PBS, images were captured with DIC software (Nikon, Tokyo, Japan). The cells on the coverslips were incubated with Hoechst 33258 staining solution for $30 \mathrm{~min}$, washed 3 times for $2 \mathrm{~min}$ with PBS and mounted on microscope slides. A fluorescence microscope (Nikon) was used to capture images using an excitation wavelength of $340 \mathrm{~nm}$. The entire experiment was performed at room temperature.

Scanning electron microscopy. Scanning electron microscopy was used for observation of morphological changes in apoptotic cells. MCF-7 cells were seeded in a 24-well plate at the density of $10^{5}$ cells $/ \mathrm{ml}$. Overnight, cells were treated with culture medium or total flavonoids at $0,0.0991,0.1982,0.3964$, 0.7928 and $1.5856 \mathrm{mg} / \mathrm{ml}$. A total of $24 \mathrm{~h}$ later, the supernatant was discarded, and the cells were washed with PBS, fixed with glutaraldehyde for $24 \mathrm{~h}$, washed 3 times with PBS for $1 \mathrm{~min}$ and then dehydrated in a gradient of alcohol solutions for $1 \mathrm{~min}$ at each concentration. Finally, the cells were soaked in tert-butyl alcohol twice for 10 min each time, dried with a vacuum pump for $24 \mathrm{~h}$ and metal spray-coated for $90 \mathrm{sec}$. The prepared specimen was observed under a scanning electron microscope.

HE staining. MCF-7 cells were seeded in a 6-well plate at $3 \times 10^{5}$ cells/well in RPMI-1640 with $10 \%$ FBS. After $24 \mathrm{~h}$, cells were treated with flavonoids at a concentration of 0 , $0.0991,0.1982,0.3964,0.7928$ or $1.5856 \mathrm{mg} / \mathrm{ml}$. Untreated cells served as the control group. After $24 \mathrm{~h}$, supernatants were discarded, and the cells were fixed with $1 \%$ paraformaldehyde for $24 \mathrm{~h}$. After washing with PBS twice, cells were stained with hematoxylin for $15 \mathrm{~min}$, differentiated in hydrochloric acid alcohol for $10 \mathrm{sec}$, treated with ammonium hydroxide for $20 \mathrm{sec}$ and stained with eosin for $10 \mathrm{~min}$, with rinses under running water after each step. Subsequently, the cells were subjected to gradient alcohol dehydration, and dimethylbenzene was used for rendering the slides transparent. Finally, the cells were mounted with resin and observed under a light microscope.

Laser scanning confocal microscopy. Laser scanning confocal microscopy was used for observation of cell morphological changes during apoptosis. MCF-7 cells were seeded in 6-well plates in RPMI-1640 media containing 10\% FBS. After $24 \mathrm{~h}$, the cells were exposed to flavonoids at concentrations of 0 , $0.0991,0.1982,0.3964,0.7928$ and $1.5856 \mathrm{mg} / \mathrm{ml}$ for $24 \mathrm{~h}$. The supernatant was discarded, and the cells were washed 3 times with PBS for 2 min each time. After incubation with $5 \mu \mathrm{l}$ Annexin $\mathrm{V}$ and $10 \mu \mathrm{l} \mathrm{PI}$ for $10 \mathrm{~min}$ in the dark, cells were washed with PBS for 2 min and images were immediately captured under a laser scanning confocal microscope.

Western blot analysis. MCF-7 cells grown in RPMI medium with $10 \%$ FBS were treated with flavonoids at different concentrations. After $24 \mathrm{~h}$, cells were harvested and disrupted in RIPA lysis buffer to extract total cellular proteins. The protein content was determined with a BAC protein determination kit (Wuhan Boshide Bio-engineering Limited Company, Wuhan, China). Total cellular proteins $(50 \mu \mathrm{g})$ were separated in $15 \%$ SDS-PAGE gels and transferred into PVDF membranes (Sigma-Aldrich) with a wet transfer system (Bio-Rad Laboratories). Membranes were blocked in 5\% non-fat milk for $1 \mathrm{~h}$ at room temperature with $5 \%$ fat-free milk dissolved in PBST buffer. Thereafter, the membranes were probed with $\beta$-actin (cat. no. ZA109; Beijing Zoman Biotechnology Co., Ltd., Beijing, China), bcl-2 (cat. no. bs-0032R; BIOSS, Beijing, China), FasL (cat. no. bs-0216R; BIOSS), caspase-3 (cat. no. ZA135; Beijing Zoman Biotechnology Co., Ltd.), caspase-9 (cat. no. ZA137; Beijing Zoman Biotechnology Co., Ltd.), p53 (cat. no. ZA120; Beijing Zoman Biotechnology Co., Ltd.) and NF-кB (cat. no. ZA131; Beijing Zoman Biotechnology Co., Ltd.) primary antibodies in TBST buffer containing $0.1 \%$ Tween-20 at 1:1,000 dilution for $24 \mathrm{~h}$ at $4^{\circ} \mathrm{C}$, followed by exposure to horseradish peroxidase-conjugated secondary antibodies (Beijing Boaosen Corporation, Beijing, China) for $90 \mathrm{~min}$ at temperature. The protein levels were visualized using a Western blot detection system, and immunoreactivities were detected with an enhanced colorimetric detection kit (Amplified Alkaline Phosphatase Goat Anti-Rabbit Immun-Blot Assay Kit, Bio-Rad Laboratories, Inc., Hercules, CA, USA).

\section{Results}

Effect of flavonoids of T. chinensis on MCF-7 cell viability. An MTT assay was performed to examine the effect of total flavonoids on cell growth. MCF-7 cells were treated with different concentrations $(0,0.0991,0.1982,0.3964,0.7928$ and $1.5856 \mathrm{mg} / \mathrm{ml}$ ) of total flavonoids for 24,48 and $72 \mathrm{~h}$. As 
Table I. Inhibition effect of T. chinensis flavonoids on MCF-7 cells detected by MTT method.

\begin{tabular}{|c|c|c|c|c|}
\hline \multirow[b]{2}{*}{ Concentration $(\mathrm{mg} / \mathrm{ml})$} & \multicolumn{4}{|c|}{ Cell growth inhibition rate by $T$. chinensis flavonoids (\%) } \\
\hline & $0 \mathrm{~h}$ & $24 \mathrm{~h}$ & $48 \mathrm{~h}$ & $72 \mathrm{~h}$ \\
\hline 0.0991 & 0 & $3.62 \pm 0.23^{\mathrm{a}, \mathrm{d}}$ & $5.14 \pm 0.11^{\mathrm{a}, \mathrm{e}}$ & $8.75 \pm 0.56^{\mathrm{a}, \mathrm{f}}$ \\
\hline 0.1982 & 0 & $24.8 \pm 0.55^{\mathrm{b}, \mathrm{d}}$ & $27.61 \pm 0.54^{\mathrm{b}, \mathrm{e}}$ & $31.76 \pm 0.69^{\mathrm{b}, \mathrm{f}}$ \\
\hline 0.3964 & 0 & $35.72 \pm 0.72^{\mathrm{c}, \mathrm{d}}$ & $46.52 \pm 0.75^{\mathrm{c}, \mathrm{e}}$ & $50.01 \pm 0.84^{\mathrm{c}, \mathrm{f}}$ \\
\hline 0.7928 & 0 & $48.03 \pm 1.34^{\mathrm{c}, \mathrm{d}}$ & $73.49 \pm 1.51^{\mathrm{c}, \mathrm{e}}$ & $77.92 \pm 1.61^{\mathrm{c}, \mathrm{f}}$ \\
\hline 1.5856 & 0 & $53.8 \pm 1.28^{\mathrm{c}, \mathrm{d}}$ & $76.76 \pm 1.83^{\mathrm{c}, \mathrm{e}}$ & $81.31 \pm 1.86^{\mathrm{c}, \mathrm{f}}$ \\
\hline
\end{tabular}

${ }^{a} \mathrm{P}<0.05,{ }^{b} \mathrm{P}<0.01$ and ${ }^{\mathrm{c}} \mathrm{P}<0.001$ for drug groups at different concentrations compared with control group, at the same time point. ${ }^{\mathrm{d}} \mathrm{P}<0.05$, ${ }^{\mathrm{e}} \mathrm{P}<0.01$ and ${ }^{\mathrm{f}} \mathrm{P}<0.001$ for different time points compared with control group, at the same drug concentration.

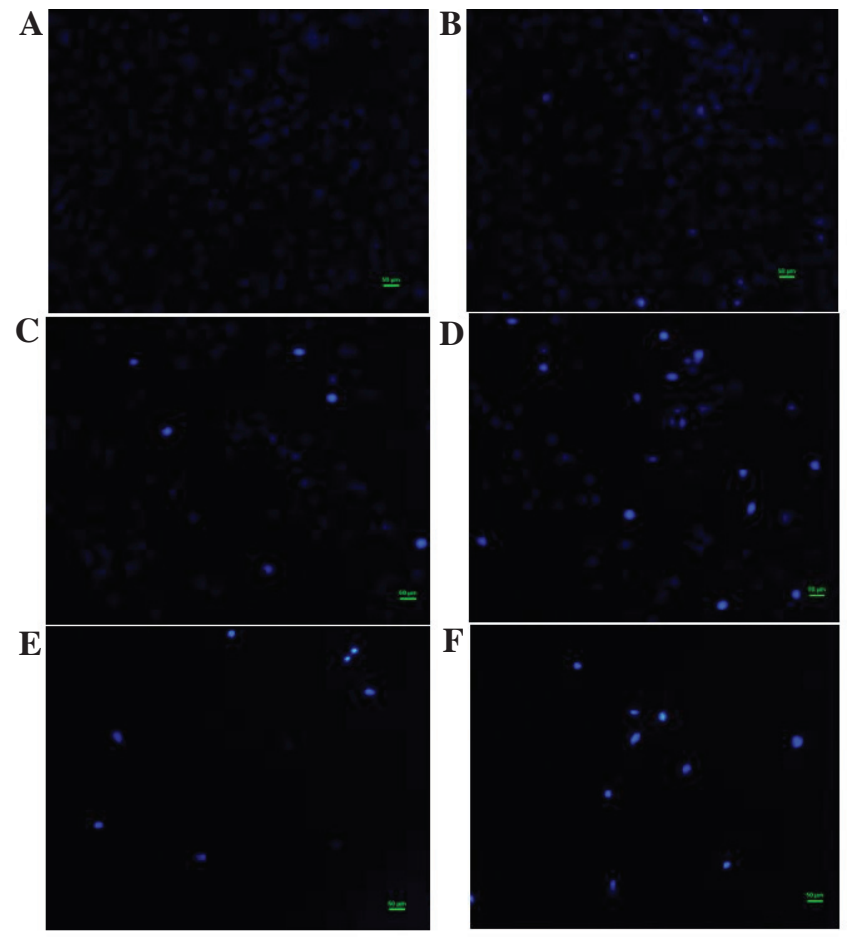

Figure 1. The apoptosis and junction changes between MCF-7 cells detected using differential interference contrast software (x400 magnification). (A) Control group, (B) 0.0991, (C) 0.1982, (D) 0.3964, (E) 0.7928 and (F) $1.5856 \mathrm{mg} / \mathrm{ml} \mathrm{T}$. chinensis flavanoids.

presented in Fig. 1, the survival of MCF-7 cells reduced in a time-dependent and dose-dependent manner. At $72 \mathrm{~h}$, the maximum inhibition ratio reached up to $81.31 \%$ at the drug concentration of $1.5856 \mathrm{mg} / \mathrm{ml}$ (Table I).

DIC microscopy analysis. In the control group, normal fusiform-shaped cells were connected and radiated outward, adhering tightly to the cover glass. With a low concentration of flavonoids $(0.0991 \mathrm{mg} / \mathrm{ml})$, the shape of cells started to change. Upon exposure to increased flavonoid concentrations $(0.1982$ and $0.3964 \mathrm{mg} / \mathrm{ml}$ ), the cells rounded up with loosened cell junctions and appeared to be vacuolated. At high concentrations of flavonoids (0.7928 and $1.5856 \mathrm{mg} / \mathrm{ml})$, fractured junctions, swelled nuclei, plasmolysis and a surge in the number of desquamated cells was observed (Fig. 1).

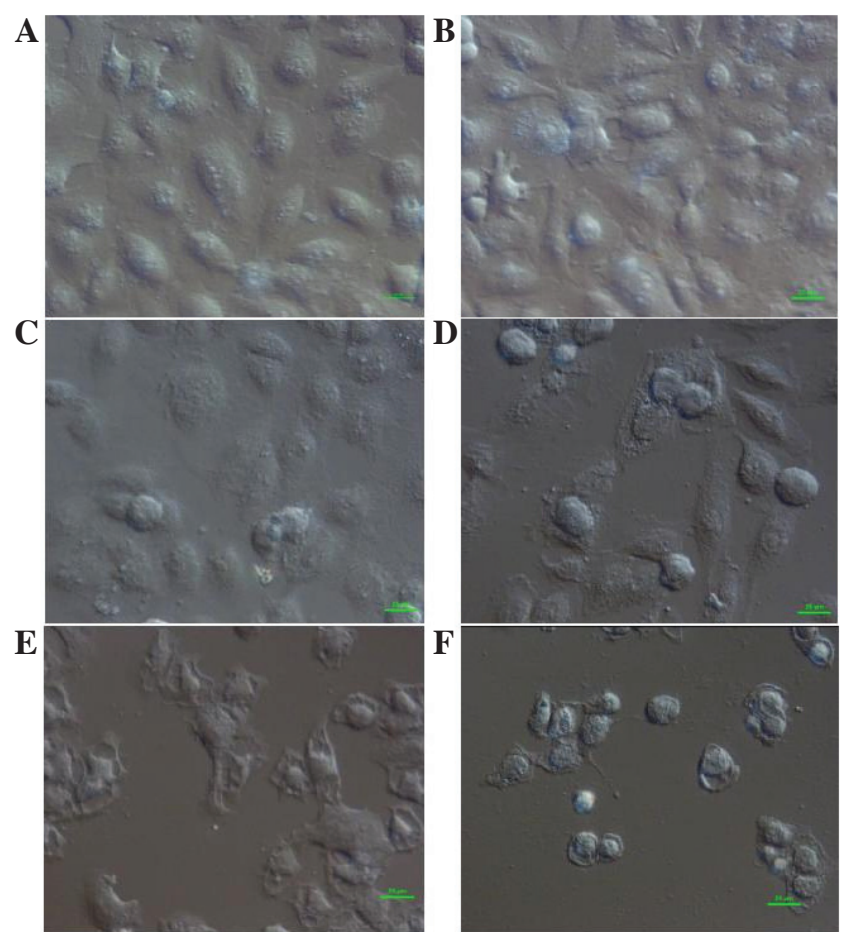

Figure 2. The effect of $T$. chinensis flavonoids on MCF-7 cell morphology detected by Hoechst 33258 method. (A) Control group, (B) 0.0991, (C) 0.1982, (D) 0.3964 , (E) 0.7928 and (F) $1.5856 \mathrm{mg} / \mathrm{ml} \mathrm{T}$. chinensis flavanoids.

Effect of flavonoids of $T$. chinensis on nuclear morphology of MCF-7 cells. To examine the cell death induced by total flavonoids, the nuclear morphology of dying MCF-7 cells stained with Hoechst 33258 dye was observed. In the control group, the nuclei of cells had a regular shape and showed a uniform distribution of low-density fluorescence. In the group exposed to a low concentration of flavonoids $(0.0991 \mathrm{mg} / \mathrm{ml})$, the nuclei of a proportion cells appeared darker than those of normal cells, indicating apoptotic cell death. In groups treated with flavonoids in the middle of the concentration range $(0.1982$ and $0.3964 \mathrm{mg} / \mathrm{ml}$ ), cell numbers gradually decreased, while the proportion of cells with hyperchromatic nuclei increased. With high concentrations of flavonoids $(0.7928$ and $1.5856 \mathrm{mg} / \mathrm{ml})$, MCF-7 cell numbers fell sharply, fragmented nuclei appeared and typical apoptotic characteristics became more apparent (Fig. 2). 

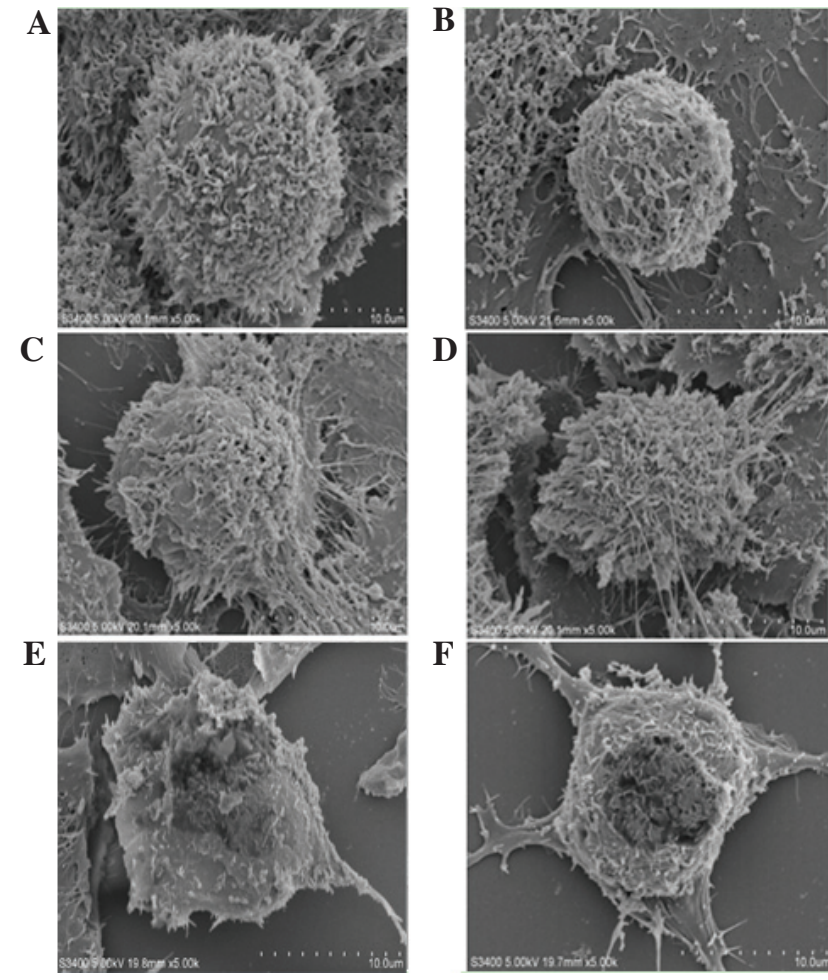

Figure 3. The apoptotic morphological changes of MCF-7 cells detected by scanning electron microscope. (A) Control group, (B) 0.0991, (C) 0.1982, (D) 0.3964, (E) 0.7928 and (F) $1.5856 \mathrm{mg} / \mathrm{ml}$ T. chinensis flavanoids.

Scanning electron microscopy analysis. MCF-7 cells in the control group were firmly adherent and covered with abundant microvilli. Those cells were connected tightly with neighboring cells and extended in all directions. In the low flavonoid concentration group $(0.0991 \mathrm{mg} / \mathrm{ml})$, cells with gap junctions shrank and showed decreased surface microvilli. In the middle concentration group $(0.1982$ and $0.3964 \mathrm{mg} / \mathrm{ml}$ ), characteristics of apoptosis became marked. With high concentrations of flavonoids (0.7928 and $1.5856 \mathrm{mg} / \mathrm{ml})$, the microvilli nearly completely disappeared, and cell membranes collapsed (Fig. 3).

HE staining analysis. In the control group, cells were in good condition and able to grow adhering to the cover glass. The nucleoplasm was uniformly stained, and mitoses could be observed. The nucleolus and nuclear membrane profiles also could be seen. At a low concentration $(0.0991 \mathrm{mg} / \mathrm{ml})$, treatment with total flavonoids halted cell division. With flavonoids in the middle range of concentrations $(0.1982$ and $0.3964 \mathrm{mg} / \mathrm{ml}$ ), intercellular spaces dilated. However, cells with condensed cytoplasm maintained their plasma membrane integrity. The cells shrank and appeared increasingly deformed or dehydrated. At high concentrations of flavonoids $(0.7928$ and $1.5856 \mathrm{mg} / \mathrm{ml})$, adherent cells were drastically reduced in number and cells were no longer intact. Cells treated with high flavonoid concentrations (0.7928 and $1.5856 \mathrm{mg} / \mathrm{ml}$ ) were more hyperchromatic than the cells of the middle concentration group (0.1982 and $0.3964 \mathrm{mg} / \mathrm{ml})$. The HE result revealed shows swollen nucleoli and fractured junctions, which was in accordance with what DIC and scanning electron microscopy results demonstrated (Fig. 4).
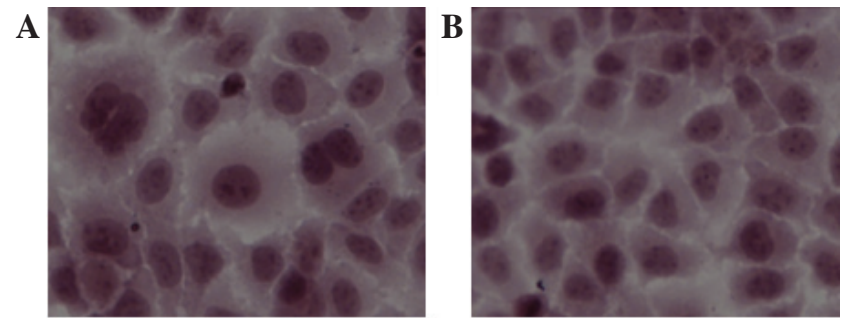

C
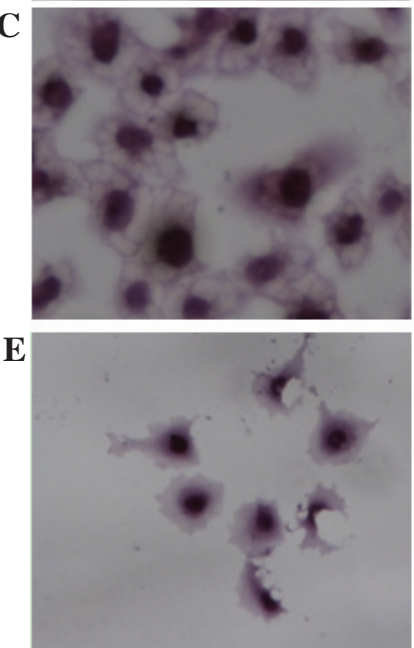

Figure 4. The nuclear and cytoplasmic changes of MCF-7 cells detected by hemotoxylin and eosin method (x400, magnification). (A) Control group, (B) 0.0991 , (C) 0.1982 , (D) 0.3964 , (E) 0.7928 and (F) $1.5856 \mathrm{mg} / \mathrm{ml}$ T. chinensis flavanoids.
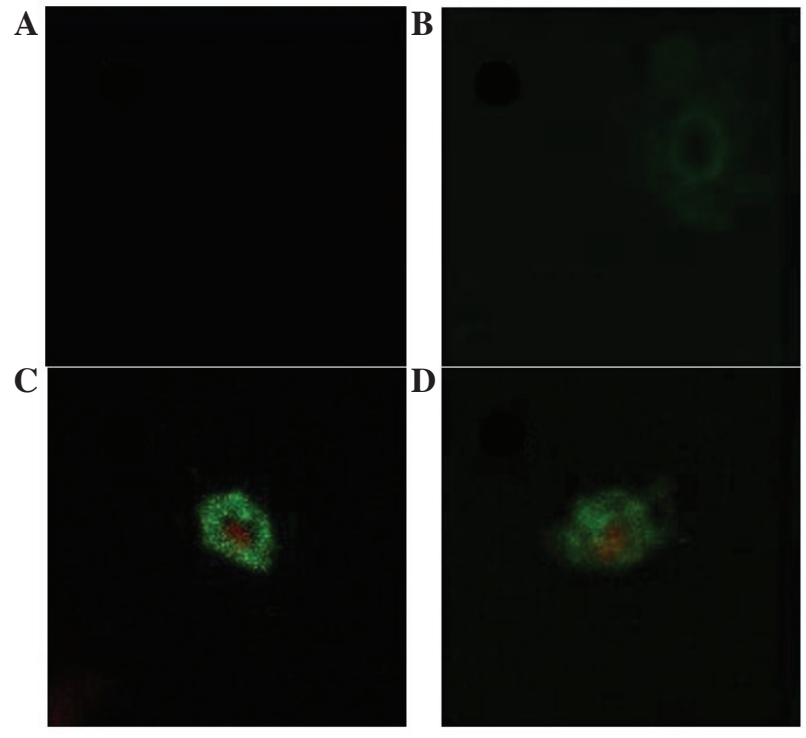

Figure 5. The apoptotic morphological change of MCF-7 cells detected by laser confocal microscopy. (A) Control group, (B) 0.0991, (C) 0.1982, (D) $0.3964 \mathrm{mg} / \mathrm{ml} \mathrm{T}$. chinensis flavanoids.

Detection of apoptosis by Annexin V-FITC/PI staining. In the control group, MCF-7 cells were not readily stained by Annexin V or PI. In the low flavonoid concentration group $(0.0991 \mathrm{mg} / \mathrm{ml})$, cells in the early stage of apoptosis were seen. Plasma cell membranes labeled green by Annexin V appeared gradually. In the middle concentration range of flavonoids $(0.1982$ and $0.3964 \mathrm{mg} / \mathrm{ml})$, the integrity of the cytomembrane was no longer intact and stained green, while the nucleus was dyed red. In the high flavonoid concentration 


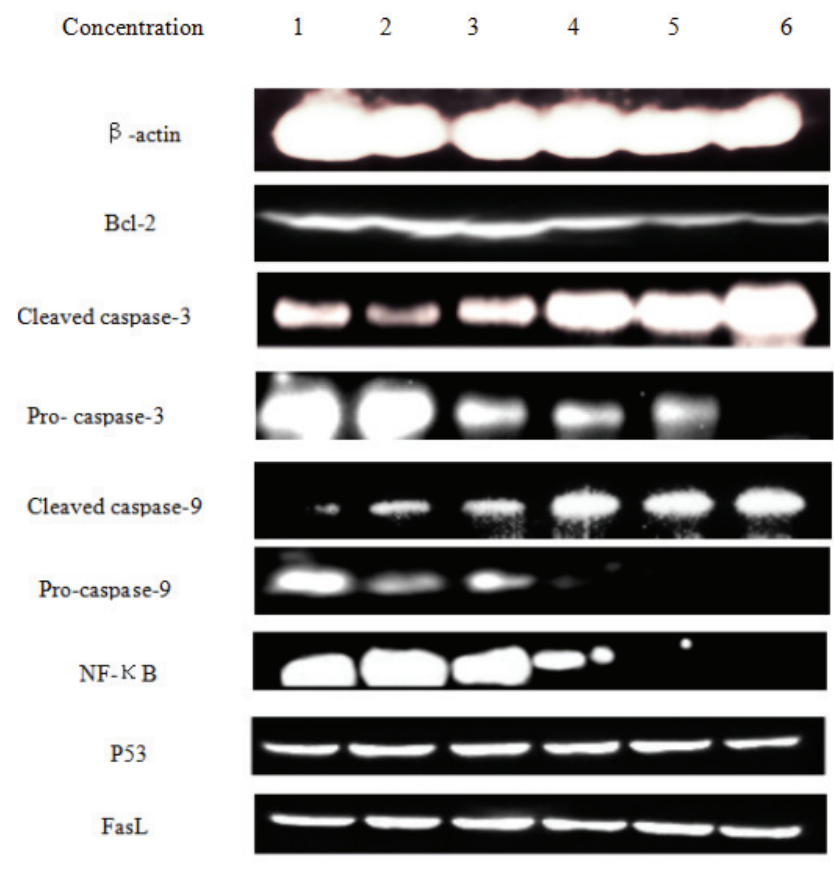

Figure 6. The expression of protein in MCF-7 cells treated with T. chinensis flavonoids detected using western blot analysis. 1, control group; 2, $0.0991 \mathrm{mg} / \mathrm{ml} ; 3,0.1982 \mathrm{mg} / \mathrm{ml} ; 4,0.3964 \mathrm{mg} / \mathrm{ml} ; 5,0.7928 \mathrm{mg} / \mathrm{ml} ; 6,1.5856 \mathrm{mg} / \mathrm{ml}$.

group $(0.7928$ and $1.5856 \mathrm{mg} / \mathrm{ml})$, both the cytomembrane and nucleus were fragmented (Fig. 5).

Effect of T.chinensis flavonoids on levels of apoptosis-associated proteins. In order to study the mechanism of flavonoid-induced apoptosis in MCF-7 cells, the expression of caspases, fasL, p53 and bcl-2 were determined. After $24 \mathrm{~h}$ of exposure to flavonoids, the expression of cleaved caspase- 3 and caspase- 9 increased in a dose-dependent manner. Bcl-2 is a crucial determinant of cell apoptosis, and a decrease in its expression was observed in the flavonoid-treated cells. This observation suggests that an intrinsic apoptotic signaling contributed to the damaging effects of flavonoids on MCF-7 cells. Total flavonoids also down-regulated the expression of $\mathrm{NF}-\kappa \mathrm{B}$, which in turn could down-regulate the expression of bcl-2. By contrast, the expression levels of p53 and fasL were not markedly changed. These findings suggest that induction of the mitochondrial pathway is crucial for flavonoid-induced apoptosis of MCF-7 cells (Fig. 6).

\section{Discussion}

In the present study, $T$. chinensis flavonoids were shown to clearly inhibit the growth and proliferation of MCF-7 cells within a certain range of concentrations $(0.0991-1.5856 \mathrm{mg} / \mathrm{ml})$ by the MTT assay. The inhibitory effect increased as the concentration or treatment time of flavonoids increased. Although the inhibition of MCF-7 cells increased with time $(24 \mathrm{~h} \leq 48 \mathrm{~h}$ $\leq 72 \mathrm{~h}$ ) when treated with flavonoids at the same concentration, a direct proportional relationship between the inhibition ratio and time was not observed. According to previous evaluation criterion (16), the effect is weak when inhibition rate is $<30 \%$; The effect is strong when inhibition rate is $>50 \%$. And the effect is modest when inhibition rate is between 30 and $50 \%$. In the present study, the inhibition rate was $58.3 \%$ when the concentration was $1.5856 \mathrm{mg} / \mathrm{ml}$ at $24 \mathrm{~h}$. The effect may therefore be described as strong and the typical apoptosis characteristics were apparent at $24 \mathrm{~h}$, therefore $24 \mathrm{~h}$ was selected as an appropriate time-point for further analyses.

The findings of the present study are in line with those of Sun et al (14) reporting that total flavonoids in T. chenensis could inhibit the proliferation of MCF-7 cells. This finding was confirmed in the present study with additional morphological observations and the corresponding mechanism was investigated.

The DIC results demonstrated that particles appeared on the surface of cells treated with drugs. 'Bubble up' demonstrated that cytoskeletal structure was damaged. Ji et al (17) observed the morphological changes in MCF-7 and MDA-MB-231 cells treated with Huaier Granule (a traditional Chinese medicine) by DIC software, and observed morphological changes induced by flavonoids that were indicative of apoptosis in MCF-7 cells.

The Hoechst results demonstrated that the nuclei of cells treated with drugs appeared darker than that of normal cells and fragmented nuclei appeared. Wang et al (18) studied the apoptotic effect of genistein on breast cancer cells by the Hoechst 33258 method and similarly to the present study, the authors observed that MCF-7 cells treated with drugs shows apoptotic morphological characteristics.

The scanning electron microscope results indicated that the microvilli on the surface of cells treated with drug of different concentrations were reduced. In the high dose group $(0.7982,1.5856 \mathrm{mg} / \mathrm{ml})$, cell membrane collapse was observed, appearing as a hole-like structure. The disruption of the cell membrane indicates cells necrosis. The typical apoptosis characteristics observed in the present study are in line with what Li et al (19) observed, in a previous study on the apoptosis of breast cancer cells induced by Herceptin. Therefore, flavonoids could induce the apoptosis of MCF-7 cells.

The HE results indicated that in the low and middle flavanoid dose group $(0.0991,0.1982,0.3964 \mathrm{mg} / \mathrm{ml})$, there were shrunken nuclei of cells dyed black-blue and intercellular gap junctions were fractured, indicating the apoptosis of cells. In the high dose group $(0.7928,1.5856 \mathrm{mg} / \mathrm{ml})$, the cells were no longer intact and the cell membrane was disrupted indicating cell necrosis. The typical apoptosis characteristics that were observed using $\mathrm{HE}$ methods were in accordance with what $\mathrm{Li}$ observed (20), in a previous study investigating the apoptosis of lung adenocarcinoma A549 cells induced by soy isoflavone and vinorelbine. These results provide further evidence that flavonoids may induce apoptosis in MCF-7 cells.

The results of laser confocal microscopy indicated that T. chinensis flavonoids at the concentration of $0.0991,0.1982$ and $0.3964 \mathrm{mg} / \mathrm{ml}$ inhibit MCF-7 cell proliferation by inducing the apoptosis of cells. However, T. chinensis flavonoids at the concentration of 0.7982 and $1.5856 \mathrm{mg} / \mathrm{ml}$ inhibit the proliferation of MCF-7 cells by inducing the necrosis of cells.

The abovementioned results reveal that morphological changes in MCF-7 cells occur via multiple pathways and from multiple perspectives, leading to the apoptosis of cells. Cell apoptosis is affected by precise control and interaction of regulatory factors, and may be activated by extracellular and intracellular stimulation. Although the apoptotic signals of cells were different, the apoptotic morphology of the cells were the same (21). A large proportion of antineoplastic drugs kill cancer cells via starting the cell apoptosis mechanism (22). 
Mitochondria are the central control sites for one mechanism of apoptosis (23). DNA injury activates the mitochondrial pathway of apoptosis, and NF- $\mathrm{KB}$ inhibits cellular apoptosis via down-regulation of bcl-2 (24). Furthermore, bcl-2 expression is able to influence mitochondrial membrane depolarization (25). Caspases form a proteolytic network within the cell whereby upstream initiator caspases are activated early in the apoptotic process (e.g., caspase-8 and caspase-9) and then activate other downstream caspases (e.g., caspase-3) (26). The activation of caspase-9 is an indicator of the activation of the mitochondrial pathway of apoptosis.

FasL, ligand of FasL, combined with FasL on the surface of cells activating caspase- 8 and -10 , when exogenous signals stimulate. Then downstream caspase- 6 and -7 are activated, caspase- 3 activation is also induced triggering the apoptosis of cells (27). p53 serves a prominent role in cell apoptosis and is an important cancer suppressor gene. The main biological activity of p53 is to identify DNA injury and to repair DNA damage. If the repair fails, p53 induces cell apoptosis to prevent the development of tumor $(28,29)$. p53 down-regulates the expression of bcl-2 to induce the apoptosis of MCF-7 cells (30).

The results of the present study demonstrate that FasL and p53 protein expression in MCF-7 cells was not changed significantly as drug concentration increased. These results indicate that flavonoids do not influence the expression of FasL and p53 protein.

In the present study, flavonoids may have down-regulated the expression of NF- $\mathrm{KB}$ and bcl-2 and no expression of NF- $\kappa B$ protein was observed in flavanoid-treated breast cancer cells. These results indicate that the decrease in NF- $\mathrm{KB}$ and bcl-2 protein levels promotes the expression of caspase- 9 and caspase-3. In addition, the expression levels of caspase- 9 and3 were up-regulated, which suggests that upstream caspase-9 protein increased to increase the expression of downstream caspase-3, the activation of caspase- 3 resulting in the degradation of cytoskeleton and DNA strand breaks inducing MCF-7 apoptosis.

In conclusion, T. chinensis flavonoids were shown to suppress the growth and induce apoptosis of MCF-7 cells. Their effects in down-regulating the expression of NF- $\mathrm{\kappa B}$ may serve to down-regulate expression of $\mathrm{Bcl}-2$, which participates in the mitochondrial pathway involving caspase- 3 and caspase- 9 to induce cell apoptosis. There is no change in FasL and p53 protein expression, so the FasL and p53 protein could not lead to the apoptosis of EC-109 cells. Therefore, T. chinensis flavonoids may have the potential to be developed as a novel anti-breast cancer drug.

\section{Acknowledgements}

The present study was financially supported by the major scientific projects of Hebei North University (grant no. ZD1314) and partly supported by the Technology Bureau of Zhangjiakou city (grant no. 11110015D).

\section{References}

1. Li SP and Jiao W: Exercise and Prevention of breast cancer. Wuhan Tiyuxue Yuan Xue Bao 48: 71-77, 2014 (In Chinese).
2. Lin FQ, Feng SQ, Li WL, et al: Antiviral ingredients research of Trollius chinensis. Zhejiang Daxue Xue Bao 31: 412, 2004 (In Chinese).

3. Li YL, Ye SM, Wang LY, et al: The isolation and bioactivity of proglobeflowery acid in Trollius macropetalus. Jinan Daxue Xue Bao 23: 124-126, 2002 (In Chinese).

4. Li LQ: The geographical distribution of Helleboroideae plants of buttercup family. Zhi Wu Fen Lei Xue Bao 33: 535-537, 1995 (In Chinese).

5. Yang GD, Rao N, Wang SH, et al: The research on antioxidant of orientin and vitexin in Trollius chinensis. Shizhen Guo Yi Guo Yao 22: 2172-3, 2011 (In Chinese).

6. Yan J, Hu H, An F, et al: The research on antioxidant of trollius flavonoids. Shizhen Guo Yi Guo Yao 22: 386-7, 2010 (In Chinese).

7. Fu XC, Li SP, Wang MW, et al: The relaxant effect and the mechanism of orientin on aorta smooth muscle. Nanfang Yi Ke Daxue Xue Bao 27: 1173-5, 2007 (In Chinese).

8. Fu XC, Li SP, Wang XG, et al: The research on antithrombotic effect of orientin. Zhong Guo Yao Fang 17: 1292-3, 2006 (In Chinese).

9. Fu XC, Li SP, Qiu YF, et al: The research on Anti-anoxia of orientin on mice of anoxia model.Zhong Guo Yao Fang 17: 654-35, 2006(In Chinese).

10. Liu P, Chen GH, Deng SH, Liu YL and Tong JM: The anti-microbial activity research of trollius flavonoids. Zhonguo Shi Yan Fang Ji Xue Zazhi 19: 207-210, 2013 (In Chinese).

11. Yan J: The antioxidant effects research of trollius flavonoids. Shizhen Guo Yi Guo Yao 21: 386-387, 2010 (In Chinese).

12. Sun L and Cheng JZ: The effect of trollius flavonoids on K562, Hela, EC-109 and NCI-H446 cells proliferation. Zhong Guo Laonian Xue Zazhi 44: 981-983, 2009 (In Chinese).

13. Sun L and Luo Q: The effect of trollius flavonoids on proliferation and apoptosis of A549 cells. Zhong Guo Laonian Xue Zazhi 31: 82-83, 2011 (In Chinese).

14. Sun Li: The effect of trollius flavonoids on breast cancer cells Zhong Guo Laonian Xue Zazhi 29: 1098-9, 2009 (In Chinese).

15. Yan J, Qu CH, Tian JM, An F and Wang SH: The study on purification of trollius flavonoids. Hebei Bei Fang Xue Yuan Xue Bao 26: 20-2, 2009.

16. Lu Y: The activity study of fermentative soy isoflavone. Dong Bei Nong Ye Da Xue, 2005 (In Chinese).

17. Ji CY: The research on effect of huaier granule on breast cancer MCF-7 (ER+) and MDA-MB-231 (ER-) cells. Nanhua Daxue, 2013 (In Chinese).

18. Wang H: The study on apoptosis of breast cancerMDA-MB-231 cells induced by genistein. Zhong Hua Ruxian Bing Zazhi 7: 322-328, 2013 (In Chinese).

19. Li HZ, Zheng Y, Lin P, Dou CM, Dong JY and Wang TW: The effect of herceptin on cell cycle and apoptosis of breast cancer cells. Ji Chuyi Xue Yu Lin Chuang 27: 1251-1256, 2007 (In Chinese).

20. Li XL: The inhibition effect of soy isoflavone and vinorelbine on lung adenocarcinoma A 549 cells. Yan Bian Daxue, 2006 (In Chinese).

21. Jimingjie, The research on cancer cell apoptosis induced by ar-curcumene. Shandong Daxue. (In Chinese).

22. Biswas DK, Martin KJ, McAlister C, Cruz AP, Graner E, Dai SC and Pardee AB: Apoptosis caused by chemotherapeutic inhibition of nuclear factor-kappaB activation. Cancer Res 63: 290-295, 2003.

23. Lee CY, Chien YS, Chiu TH, Huang WW, Lu CC, Chiang JH and Yang JS: Apoptosis triggered by vitexin in U937 human leukemia cells via a mitochondrial signaling pathway. Oncol Rep 28: 1883-1888, 2012.

24. Chen DY, Zhai ZH and Shu HB: The regulating mechanism of NF- $\kappa$ B activation. Ke Xue Tong Bao 48: 1893-911, 2003 (In Chinese).

25. Orrenius S: Reactive oxygen species in mitochondrial-mediated cell death. Drug Meteb Rev 39: 443-455, 2007.

26. Blanc C, Deveraux QL, Krajewski S, Jänicke RU, Porter AG, Reed JC, Jaggi R and Marti A: Caspase-3 is essential for procaspase-9 processing and cisplatin-induced apoptosis of MCF-7 breast cancer cells. Cancer Res 60: 4386-4390, 2000.

27. Reesink- Peters N, Hougardy BM, Hoor KA, van den Heuvel FA, Ten Hoor KA, Hollema H, Boezen HM, de Vries EG, de Jong S and van der Zee AG: Death recePtors and ligands in cervical carcinogenesis: An immunohistochemical study. Gynecol Oncol 96: 705-713, 2005.

28. Asker C, Wiman KG and Selivanova G: P53-induced apoptosis as a safeguard against cancer. Biochem Biophys Res Commun 265: 1-6, 1999.

29. Sheikh MS and Furnace AJ Jr: Role of p53 family members in apoptosis. J Cell Phvsiol 182: 171-181, 2000.

30. Zhangping: The research on cancer cell apoptosis induced by flavonoids from seed residues and the corresponding mechanism. Hua Dong Shi Fan Da Xue, 2004 (In Chinese). 